\title{
Effect of Balance Ability and Walking in the Elderly by Taekwon-do Program
}

\author{
Jun-hyun Kim, PT, MS, Sung-jin Park, PT, $\mathrm{PhD}^{1}$ \\ Department of Physical Therapy, Daegu Catholic UNIV. Medical Center \\ ${ }^{I}$ Department of Physical Therapy, Sling Institute
}

\author{
태권도 프로그램이 노인의 체중심 동요와 보행에 미치는 영향 \\ 김준현 $\cdot$ 박성진 ${ }^{1}$ \\ 대구가톨릭대학병원 물리치료실, ${ }^{1}$ 슬링연구소
}

\begin{abstract}
$<$ Abstract $>$
연구목적 : 본 연구의 목적은 태권도 프로그램이 노인의 균형능력에 어떠한 영향을 미치는지에 대해 알아보는 것이다.

연구방법 : 대상자는 본 연구에 대해 설명을 들은 후 자원한자로서 65 세 이상의 노인이었다. 실험군은 태권도 프로그램 그룹으로서 17명이었다. 태권도 프로그램을 주3회씩 6주간 시행하였고 모든 대상자의 균형능력을 평 가하기위하여 BPM, GAITrite, Berg 균형척도를 실험전후로 평가하여 자료를 수집하였다. 수집된 자료는 SPSS 14.0 으로 대응표본 t-test를 사용하여 유의수준 $a=.05$ 에서 통계 처리 하였다.

연구결과 : 태권도 프로그램을 시행한 결과 프로그램 실행 전에 비해 오른쪽 활보폭, 왼쪽 보폭, 왼쪽 활보폭, 버그 균형척도에서 통계적으로 유의한 증가를 나타내었다. 그리고 최대 동요속도, 동요거리, 오른쪽 기저 지지 면, 오른쪽 양하지 지지기, 왼쪽 기저지지면, 왼쪽 양하지 지지기에서 통계적으로 유의한 감소가 있었다.

결론 : 태권도 프로그램을 시행한 결과 오른쪽 활보폭, 왼쪽 보폭, 왼쪽 활보폭, 버그 균형척도에서 유의한 증 가와 최대 동요속도, 동요거리, 오른쪽 기저 지지면, 오른쪽 양하지 지지기, 왼쪽 기저지지면, 왼쪽 양하지 지 지기에서 유의한 감소는 균형 제어에 긍정적인 영향을 미칠 것으로 판단된다. 따라서 이러한 균형 제어 능력 의 향상은 노인의 보행에 있어서의 낙상 예방에 효과적일 것으로 사료된다.
\end{abstract}

핵심단어 : 태권도 품새동작, 균형능력, 보행, 체중심 동요.

\section{I . Introduction}

Aging weakens the stamina and overall physical functions, making older people more prone to poor

교신저자 : 김준현, E-mail: colorhorsered@hanmail.net

논문접수일 : 2012년 03월 19일 / 수정접수일 : 2012년 06월 21일 / 게재승인일 : 2012년 07월 06일 
eyesight or balance impairments which place them at greater risk of frequent falls (Hagemane et al, 1995). As the elderly lose their ability to regain their balance, their maximum muscular strength decreases, the time required for new muscle formation shortens, and the general physical and mental functions related to walking deteriorates (Park Sun-Jin et al., 2009).

The elderly with weak physical and mental constitutions find it increasingly difficult to perform basic activities of daily living (BADL) and instrumental activities of daily living (IADL), which becomes an obstacle to pursuing an independent daily life. Continuous health management of the elderly is required to address these issues, and elderly exercise is the most efficient solution that guarantees maximum results without imposing demanding personal and social costs (Kim Soo-min, 2006).

Elderly exercise helps enhance health; remedy physical weaknesses; improve muscle strength, muscle endurance, cardiovascular endurance, and flexibility, which are basic building blocks of healthy physical constitution; and boosts immune functions, which makes it less likely to develop cancer, chronic degenerative diseases, and other illnesses (Morey et al, 2002). Exercise also strengthens the bone, improves flexibility, and enhances overall blood circulation and balance functions among the elderly (Fatouros et al, 2002). A prior study by Tang and Woollocott (1998) demonstrates the loss of balance among the elderly when compared to the younger population, and this loss of balance greatly increases the risk of falling (Shumway-cook et al, 1997). Injuries from balancerelated falls are a common cause of death among the elderly, and thus, numerous exercises designed to improve balance are being researched for practical application.

Changing sense of balance is the leading cause of falls among the elderly (Silsupadol et al, 2006; Duncan et al, 1992), and a person's shortcomings in balance functions has a high correlation with the frequency of falls (Hindmarsh and Estes, 1989; Horak et al, 1989). Park Kyung-hye and Lee Yoonhwan (2006) claim that simple exercise is insufficient to address these problems, and that a proper measure should incorporate social activities, which also play a key role in improving body functions. Thus, leisure activities of a social nature are gaining more attention, as can be seen by the growing interest in tai chi. The APTA (American Physical Therapy Association) manual on balancerelated exercises to prevent falls (APTA, 1999) also makes a reference to tai chi, and numerous literature in the sector report tai chi's effectiveness in raising the balance functions of a person (Tsang and Hui-Chan, 2006).

Taekwondo is Korea's national sport and traditional school of martial arts. Though it had been believed that taekwondo's highly controlled and energetic movements make it a difficult exercise to master for the elderly, recent broadcasts have shown examples where the elderly successfully train in the taekwondo arts, while several studies suggest the positive impact of taekwondo on the health of the elderly (Moon Dae-Sung, 2005; Kim Ki-man, 2006). Nonetheless, there is insufficient research on the impact of taekwondo on balance functions, and this study aims to fill in this gap by conducting the following experiment.

\section{Methods}

\section{Subjects}

The participants of this study were elderly people aged 65 or higher, who were explained the main objective of this research and voluntarily participated in the study by signing the consent form( $\mathrm{n}=17$ for 
Effect of Balance Ability and Walking in the Elderly by Taekwon-do Program

Taekwondo program: age: $75.58 \pm 0.58$ yrs., height: $155.76 \pm 1.15 \mathrm{~cm}$, weight: $52.64 \pm 1.57 \mathrm{~kg}$ ).

\section{Instruments and measurements}

1) Instruments

This study divided the participants into the effects of the exercise before and after the experiment. First, we conducted an interview to understand the general characteristics of the participants. To measure the static balance, we used the BPM (Balance Performance Monitor: Dataprint software 5.3, SMS Healthcare Inc. UK) for 30 seconds to measure the maximum oscillation velocity, oscillation distance, and oscillation area. To gauge the dynamic balance, we used a GAITrite system (MAP/CIR. INC. USA) measuring $61 \mathrm{~cm}$ in width and $366 \mathrm{~cm}$ in length to find step length, stride length, and base of support. The Berg balance test was also conducted before and after the experiment by a physical therapist who was not informed of the details of the experiment. The Berg balance test consists of 14 categories that score from 0 to 56 points maximum, and is a widely used measure of balance with high reliability and internal validity (Bogle and Newton, 1996).

\section{2) Procedure}

The experimental group was required to do the following exercises in the course of 6 weeks: 10 minutes of warm up exercises; 5minutes of kicks and 5minutes of punches in the taekwondo program; 2sets (20minutes) of palgue in the poomsae training; and 5minutes of cool down exercises. The taekwondo program for the experimental group was designed for beginners, with most movements being relatively simple. The 2palgue sets which have higher frequency of the apgubi (forward stance) were included, while the participants received poomsae training lweek before the experiments.

\section{Analysis}

Paired t-test was used to analyse the relationship between before and after training of each group (SPSS ver. 14.0, $a=.05$ ).

\section{Results}

1. comparison of balance ability between before and after Taekwondo program

Our results for the experimental group showed that the maximum oscillation velocity decreased from 50.82 before the experiment to 38.00 after the experiment $(p<.05)$. The oscillation distance also yielded a statistically meaningful result by decreasing from 357.64 to 281.76 after the experiment $(p<.05)$. The participants' right stride length made a statistically meaningful increase from 98.07 to 102.96 after the exercises $(\mathrm{p}<.05)$, while their right - base of support was reduced from 7.10 to 5.00 $(\mathrm{p}<.05)$. The right double limb support time also

Table 1. comparison of balance ability between before and after Tagwondo program

\begin{tabular}{ccc}
\hline \hline factors & \multicolumn{2}{c}{ group } \\
\cline { 2 - 3 } & before & after \\
\hline maximum oscillation $(\mathrm{mm} / \mathrm{sec})$ & $50.82 \pm 3.56^{*}$ & $38.00 \pm 3.13^{*}$ \\
oscillation distance $(\mathrm{mm})$ & $357.64 \pm 33.07^{*}$ & $281.76 \pm 25.23^{*}$ \\
oscillation area $\left(\mathrm{mm}^{2}\right)$ & $361.82 \pm 76.03$ & $295.58 \pm 68.43$ \\
Berg's balance scale & $45.70 \pm .58^{*}$ & $50.52 \pm .55^{*}$ \\
\hline
\end{tabular}

Note. *significant difference between before and the after 
대한물리의학회지 제 7 권 제 3 호

Table 2. comparison of walking between before and after Tagwondo program

\begin{tabular}{lcc}
\hline \multicolumn{1}{c}{ factors } & \multicolumn{2}{c}{ group } \\
\cline { 2 - 3 } & before & after \\
\hline right gait time(sec) & $.19 \pm .00$ & $.19 \pm .00$ \\
right step length $(\mathrm{cm})$ & $49.07 \pm 1.35$ & $51.49 \pm 1.93$ \\
right stride length(cm) & $98.07 \pm 2.41^{*}$ & $102.96 \pm 3.55^{*}$ \\
right base of support(cm) & $7.10 \pm .54^{*}$ & $5.00 \pm 1.34^{*}$ \\
right single limb support time(\%) & $40.62 \pm .55$ & $41.05 \pm .39$ \\
right double limb support time(\%) & $21.64 \pm .53^{*}$ & $19.75 \pm .93^{*}$ \\
left gait time(sec) & $.20 \pm .00$ & $.20 \pm .00$ \\
left step length(cm) & $47.58 \pm 1.22^{*}$ & $51.30 \pm 1.59^{*}$ \\
left stride length(cm) & $96.22 \pm 2.14^{*}$ & $101.28 \pm 2.67^{*}$ \\
left base of support(cm) & $7.01 \pm .54$ & $5.25 \pm 1.34$ \\
left single limb support time(\%) & $37.64 \pm .40^{*}$ & $39.43 \pm .68^{*}$ \\
left double limb support time(\%) & $21.67 \pm .67$ & $21.16 \pm .92$ \\
\hline
\end{tabular}

Note. *significant difference between before and the after

made a significant decrease from 21.64 to 19.75 $(\mathrm{p}<.05)$.

Likewise, the left step length made a statistically meaningful increase from 47.58 to $51.30(p<.05)$, while the left stride length also increased from 96.22 to $101.28 \quad(p<.05)$. The left base of support fell from 7.01 to 5.25 after the exercises, but the change was statistically irrelevant ( $>$.05). The left - single limb support time made a meaningful increase from 37.64 to $39.43 \quad(p<.05)$, while the Berg's scale results also posted a growth from 45.70 to 50.52, which carries great statistical implications $(\mathrm{p}<.05)$.

There were no statistically significant changes in oscillation area, right step length, right gait time, right single limb support time, left gait time, and left double limb support time (table 1,2).

\section{Discussion}

Balance is the basic function required to maintain a stance or pursue purposeful physical activities, but this function deteriorates with age (Piirola and Era, 2006; Woollacott and Shumway-Cook, 1990).
According to Papa and Cappozzo (2000), the muscular activity and coordination of the elderly are severely impaired when compared against the younger population, which hinders their balancing abilities, slows down their activity speed, and increases oscillation in their stances (Carter et al, 2001). Aging also causes the walking habits to change by slowing down the walking speed, decreasing step length, and widening the support base during the swing phase (Kang soon-hee et al, 2002). Falls among the elderly are serious problems which can cause serious injuries and fractures, impair their basic functions and create difficulties in conducting daily lives, and can even cause death by complications (Kauffman, 1999).

Exercises are the most commonly used methods to mediate against these risks and improve the balance functions of the elderly. Exercise programs help to reduce the internal factors that cause falls among the elderly (Chang et al, 2004). Furthermore, Topp et al (1996) claim that exercise improves the quality of life among senior citizens, while Roddey et al (2002) argue that exercise helps to reduce the rising cost associated with health maintenance. 
Effect of Balance Ability and Walking in the Elderly by Taekwon-do Program

Numerous studies have aimed to find the proper exercise to address the balance problem among the elderly, but tai chi has received the most acclaim. Tai chi is an exercise that originated in China, and studies have reported that practicing tai chi helps mediate the risk of falls (Taggart, 2002) while also enabling greater social activities through recreation and group coordinated movements.

This study used BPM tests to gauge the effectiveness of taekwondo on oscillation. Analyzing our results on maximum oscillation velocity, oscillation area, oscillation distance, we find that oscillation distance and oscillation velocity made statistically significant decreases. While the maximum oscillation velocity yielded no meaningful results, there were noticeable numerical improvements. Prince et al (1997) argued that aging causes the sense of balance and orientation response to decrease, which results to greater oscillation in maintaining a particular stance. The elderly show greater oscillation in size and frequency when compared to younger people (Roberts and Fitzpatrick, 1983), while their reaction time slows (Thelen et al, 1996). Thus, our results show that the taekwondo program has increased the participants' abilities concerning oscillation.

The Berg's scale results of this study showed that the experimental group exercising in taekwondo scored higher after the experiment, from 48.44 to 52.11. The Berg test is a commonly used instrument to gauge the effects of the fall, and is used frequently in this area of research. Bogle and Newton (1996) claimed that a Berg score of 45 out of 56 points indicates higher probability to experience falls, while Harada et al (1995) claimed that a score of 48points should be the base line for measuring likeliness to experience falls. Before the experiment, the experimental group's Berg scores averaged 48.44points, which is not in the high-risk group but very close to the base line. After the experiment, the group's average score increased to above 50points, which signifies a much lower risk of experiencing falls.

This study also used the GAITrite to assess the impact on walking abilities. Our results showed that the taekwondo program yielded statistically meaningful increases in the right stride length, left step length, left stride length, and left single limb support time and statistically meaningful decreases in the right base of support, right double limb support time, and left - base of support. The right step length and right single limb support time posted numerical increases, though they did not rise to the point of being statistically meaningful, while the right gait time, left gait time, and left double limb support time made numerical decreases that were not statistically meaningful.

Kwon Hyuk-cheol and Kong Jin-yong (2003) argue that analyzing the walking step data of the elderly provides information on their risks related to falls and stressed the importance of an objective assessment. The GAITrite system generates an accurate numerical measure of the changes in a person's walking patterns, and is a commonly used tool in clinical studies (Kressing et al, 2004).

Aging is said to bring changes to the walking habits by slowing the step speed, reducing step lengths, widening the base of support, and requiring longer time for double limb support (Kang soon-hee et al, 2002). The results from this study showed increases in the step length, decreases in the base of support, and decrease in the time for double limb support, while there was a correlation with the step speed. Furthermore, the step length, stride length, base of support, double limb support time for both limbs showed statistically meaningful correlation. The right and left stride lengths had the highest correlation. Woolley et al (1997) found that senior population having experience with falls had a significant decrease in stride length, and claimed 
that changes in stride length is a significant indicator of predicting falls (Woo et al, 1999). Our results thus show that the taekwondo program has a positive impact on the walking abilities and balance abilities of the elderly and has a positive effect in decreasing the risk of falls.

\section{Conclusion}

The significant increase in right stride length, left step length, left stride length, and the Berg's scale and the meaningful decrease in maximum oscillation velocity, oscillation distance, right base of support, right double limb support time, left base of support, and left double limb support time after following the taekwondo regimen is assessed to have a positive effect on balance control. Furthermore, these improvements in the balancing abilities are expected to be effective in preventing potentially dangerous falls among the elderly.

\section{References}

Kang Soon-hee, Kim Soon-ja, Kim Young-hee et al. Geriatric physical therapy. Seoul. Hyunmoonsa. 2002.

Kwon Hyuk-cheol, Kong Jin-yong. Comparison of the Functional Ambulation Performance Scores of Senior Adults With or Without a History of Falls. Korean Academy of university trained physical therapists. 2003;10(1):1-13.

Kim Ki-man. Effectiveness of Taekwondo Apkubi Momtong BandaeJireugi as diagnostic method of health related to muscle strength level of elderly men. Ggraduate School Kyeimyung University . Unpublished doctoral thesis. 2006.

Kim Soo-min. A study of self exercise program for the health of aged. Journal of Sports Science Research. 2006;24(1):31-45.

Moon Dae-Sung. A Study on the Possibility of
Lifelong Taekwondo. Journal of Korea Sport research. 2005;16(3):889-95.

Park Kyung-hye, Lee Yoon-hwan. Effect of social activities on physical functioning in communitydwelling older persons: Examination of causal relationships. Journal of Korean Gerontological Society. 2006;26(2):275-89.

Park Sun-jin, Lee Soon-chul, Kim In-seok. The Walking Ability and Crossing Behavior in Elderly People. Journal of The Korean Data Analysis Society. 2009;11(6):3071-87.

APTA(american physical therapy association). What you need to know about Balance and falls. 1999.

Bogle Thorbahn LD, Newton RA. Use of the Berg balance test to predict falls in elderly persons. Phys Ther. 1996;76(6):576-83.

Carter ND, Kannus P, Khan KM. Exercise in the prevention of falls in older people: a systematic literature review examining the rationale and the evidence. Sports Med. 2001;31(6):427-38.

Chang JT, Morton SC, Rubenstein LZ et al. Interventions for the prevention of falls in older adults: Systematic review and meta-analysis of randomised clinical trials. BMJ. 2004:328(20): 680-6.

Duncan PW, Studenski S, Chandler J et al. Functional reach: predictive validity in a sample of elderly male veterans. J Gerontol. 1992;47(3): M93-8.

Fatouros IG, Taxildaris K, Tokmakidis SP et al. The effects of strength training, cardiovascular training and their combination on flexibility of inactive older adults. Int J Sports Med. 2002; 23(2):112-9.

Hageman PA, Leibowitz JM, Blanke D. Age and gender effects on postural control measures. Arch Phys Med Rehabil. 1995;76(10):961-5.

Harada N, Chiu V, Damron-Rodriguez Z et al. Screening for balance and mobility impairment in elderly individuals living in residential care 
facilities. Phys Ther. 1995;75(6):462-9.

Hindmarsh JJ, Estes EH Jr. Falls in older persons. Causes and interventions. Arch Intern Med. 1989;149(10):2217-22.

Horak FB, Shupert CL, Mirka A. components of postural dyscontrol in the elderly: a review. Neurobiol Aging. 1989;10(6):727-38.

Kauffman TL. Geriatric Rehabilition Manual. Philadelphia. Churchill Livingstone. 1999.

Kressing RW, Gregor RJ, Oliver A et al. Temporal and spatial features of gait in older adults transitioning to frailty. Gait Posture. 2004;20(1): $30-5$.

Morey MC, Pieper CF, Crowley GM et al. Exercise Adherence and 10-year Mortality in Chronically III Older adults. J Am Geriatr Soc. 2002;50(12): 1929-33.

Papa E, Cappazzo A. Sit-to-stand motor strategies investigated in able-bodied young and elderly subjects. J Biomech. 2000;33(9):1113-22.

Piirtola M, Era P. Force platform measurements as predictors of falls among older peaple: a review. Gerontology. 2006;52(1):1-16.

Prince F, Corriveau H, Hebert $\mathrm{R}$ et al. Gait in the elderly. Gait Posture. 1997;5(2):128-35.

Roberts BL, Fitzpatrick JJ. Improving Balance: Therapy of movement. J Gerontol Nurs. 1983;9 (3):151-6.

Roddey TS, Olson SL, Gartsman GM et al. A randomized controlled trial comparing 2 instructional approaches to home exercise instruction following arthroscopic full-thickness rotator cuff repair surgery. J Orthop Sports Phys Ther. 2002;32 (11):548-59.

Silsupadol P, Siu KC, Shumway-Cook A et al. Training Balance under single and dual-task conditions in older adults with balance impairments. Phys Ther. 2006;86(2):269-81.

Shumway-Cook A, Baldwin M, Polissar NL et al. Predicting the probability for falls in communitydwelling older adults. Phys Ther. 1997;77(8): 812-9.

Taggart HM. Effects of tai chi exercise on balance, functionnal mobility, and fear of falling among older women. Appl Nurs Res. 2002;15(4):235-42.

Tang PF, Woollacott MH. Inefficient postural responses to unexpected slips during walking in older adults. J Gerontol A Biol Sci Med Sci. 1998;53(6):M471-80.

Thelen E, Corbetta D, Spencer JP. Development of reaching during the first year: role of movement speed. J Exp Psychol Hum Percept Perform. 1996;22(5):1059-76.

Topp R, Mikesky A, Dayhoff NE et al. Effect of resistance training on strength, postural control, and gait velocity among older adults. Clin Nurs Res. 1996;5(4):407-27.

Tsang WW, Hui-Chan CW. Standing balance after vestibular stimulation in tai chi-Practicing and Nonpracticing healthy older adults. Arch Phys Med Rehabil. 2006;87(4):546-53.

Woollacoot MH, Shumway-Cook A. Changed in posture control across the life span: a Systems approach. Phys Ther. 1990;70(12):799-807.

Woo J, Ho SC, Yu AL. Walking speed and stride length predicts 36 months dependency, mortality, and institutionalization in Chinese aged 70 and older. J Am Geriatr Soc. 1999;47(10):1257-60.

Woolley SM, Czaja SJ, Druy CG. An assessment of falls in elderly men and women. J Gerontol A Biol Sci Med Sci. 1997;52(2):M80-7. 